\title{
Botulinum toxin type A injection increases range of motion in hip, knee and ankle joint contractures of children with cerebral palsy
}

\author{
Botulinum toksin tip A enjeksiyonu serebral palsili çocukların kalça, diz \\ ve ayak bileği eklemi kontraktürlerinde hareket açıkığını artırır
}

\author{
Erdem Aktaş, MD (D), Hakan Ömeroğlu, MD D \\ Department of Orthopedics and Traumatology, TOBB University of Economics and Technology, Faculty of Medicine, Ankara, Turkey
}

\begin{abstract}
Objectives: This study aims to evaluate the clinical outcomes of children with spastic type cerebral palsy $(\mathrm{CP})$ treated with botulinum toxin type A (BoNT-A) injection for lower limb contracture and the influence of age, gender, functional level and degree of initial contracture on treatment outcomes.
\end{abstract}

Patients and methods: Clinical records at pre-BoNT-A injection and post-BoNT-A injections of 153 sessions of a total of 118 consecutive children (67 boys, 51 girls; mean age 5.9 \pm 2.6 years; range, 2.5-16 years) were retrospectively evaluated. Degrees of pre- and post-injection contracture were evaluated. Post-injection supplemental casting for 10 days was recorded in all cases. Less than $20^{\circ}$ of hip flexion contracture, more than $30^{\circ}$ of hip abduction, a negative prone Ely test, less than $50^{\circ}$ of popliteal angle and at least $5^{\circ}$ of ankle dorsiflexion values at post-injection were accepted as sufficient clinical improvement.

Results: Sufficient post-injection range of motion (ROM) was observed in $80 \%$ of cases with hip flexion contracture, in $45 \%$ of cases with hip adduction contracture, in $84 \%$ of cases with knee flexion contracture and in $77 \%$ of cases with ankle equinus contracture. Prone Ely test that was positive in $60 \%$ of cases with knee extension contracture was negative at post-injection. Improvement in contractures were prominent in children with lesser degree initial contractures.

Conclusion: Botulinum toxin type A injection increases $\mathrm{ROM}$ in hip, knee and ankle joint contractures in CP. Although age, gender and functional level may influence the clinical outcomes, pre-treatment level of contracture is the main determinant in improvement in ROM at post-injection.

Keywords: Botulinum toxin type A, cerebral palsy, lower limb contracture.

\section{ÖZ}

Amaç: $\mathrm{Bu}$ çalışmada alt ekstremite kontraktürü nedeniyle botulinum toksin tip A (BoNT-A) enjeksiyonu ile tedavi edilen spastik tip serebral palsi (SP)'li çocukların klinik sonuçları ve yaşın, cinsiyetin, fonksiyonel düzeyin ve başlangıç kontraktür derecesinin tedavi sonuçlarına etkisi değerlendirildi.

Hastalar ve yöntemler: Toplam 118 ardişık çocuğun (67 erkek, 51 kız; ort. yaş 5.9 \pm 2.6 yıl; dağılım, 2.5-16 yıl) BoNT-A enjeksiyonu öncesi ve 153 seanslık BoNT-A enjeksiyonu sonrası klinik kayıtları retrospektif olarak değerlendirildi. Enjeksiyon öncesi ve sonrası kontraktür dereceleri değerlendirildi. Tüm olgularda enjeksiyon sonrası 10 günlük tamamlayıcı alçı uygulaması kayıt edildi. Enjeksiyon sonrası $20^{\circ}$ 'nin altında kalça fleksiyon kontraktürü, $30^{\circ}$ 'den fazla kalça abdüksiyonu, negatif pron Ely testi, $50^{\circ}$ 'nin altında popliteal açı ve en az $5^{\circ}$ ayak bileği dorsifleksiyon değerleri yeterli klinik düzelme olarak kabul edildi.

Bulgular: Kalçafleksiyon kontraktürü olan olguların \%80'inde, kalça adduksiyon kontraktürü olan olguların \%45'inde, diz fleksiyon kontraktürü olan olguların \%84'ünde ve ayak bileği ekin kontraktürü olan olguların \%77'sinde enjeksiyon sonrası yeterli eklem hareket açıklığı (EHA) görüldü. Diz ekstansiyon kontraktürü olan olguların \%60'ında pozitif olan pron Ely testi enjeksiyon sonrası negatif idi. Başlangıç kontraktür düzeyi daha düşük olan çocuklarda kontraktürde iyileşme belirgin idi.

Sonuç: Botulinum toksin tip A enjeksiyonu SP'de kalça, diz ve ayak bileği kontraktürlerinde EHA'yı artırır. Yaş, cinsiyet ve fonksiyonel düzey klinik sonuçları etkileyebilse de enjeksiyon sonrası EHA'daki iyileşme üzerinde temel belirleyici tedavi öncesi kontraktür derecesidir.

Anahtar sözcükler: Botulinum toksin tip A, serebral palsi, alt ekstremite kontraktürü.

Received: February 13, 2019 Accepted: May 11, 2019 Published online: May 30, 2019

Correspondence: Erdem Akłaş, MD. TOBB Ekonomi ve Teknoloji Üniversitesi Tıp Fakültesi, Ortopedi ve Travmatoloji Anabilim Dalı, 065ı Söğütözü, Ankara, Turkey. Tel: +90532-3781355 e-mail: drerdem2007@gmail.com 
Cerebral palsy $(\mathrm{CP})$ is a damage of the immature brain before or during birth or in postpartum early childhood. Although brain damage is nonprogressive, clinical picture may vary. Among the broad spectrum of physical and cognitive disabilities depending on the severity and localization of damage, impairment of agonist-antagonist muscle coordination is one of the main determinants. In the recent past, the treatment options for $\mathrm{CP}$ patients have expanded. Treatment options range from physical and occupational therapy to medical therapy and complex surgical procedures. Resolving hypertonicity is one of the mainstays of treatment in $\mathrm{CP}$ and various medications and surgical interventions are being used accordingly. Botulinum toxin type A (BoNT-A), one of the local medical therapy methods, inhibits the release of acetylcholine in neuromuscular junctions and leads to flaccid paralysis in the affected muscles. This therapy leads to a safe and selective spasticity reduction and is primarily used as an adjunct to physical and occupational therapy in targeted muscles with a reversible effect that lasts up to 3-6 months. Botulinum toxin type A injections have emerged as an effective and safe therapy in $\mathrm{CP}$ patients of all levels of functional disability and have begun to be widely used to manage dynamic contractures of both upper and lower limbs. The two major goals of this treatment method are to lessen daily functional impairment and to delay the need for orthopedic surgery in the advanced stages. ${ }^{[1]}$ To date, favorable functional outcomes of BoNT-A application in both ambulatory and non-ambulatory children with $\mathrm{CP}$ have been reported in several articles. ${ }^{[2-6]}$

We hypothesized that BoNT-A would improve the clinical outcome in spastic type CP patients with different levels of walking capability and that this improvement might be affected by some patient related factors. Therefore, in this study, we aimed to evaluate the clinical outcomes of children with spastic type CP treated with BoNT-A injection for lower limb contracture and the influence of age, gender, functional level and degree of initial contracture on treatment outcomes.

\section{PATIENTS AND METHODS}

This study was conducted at Osmangazi University Faculty of Medicine between February 2007 and December 2013 and included a retrospective analysis of the clinical records of 118 consecutive children ( 67 boys, 51 girls; mean age $5.9 \pm 2.6$ years; range, 2.5-16 years) who had complete recorded data and whose lower limb contractures due to spastic type CP were treated by BoNT-A injections in the lower limb muscles in a total of 153 sessions by the same surgeon (senior author). Eighty-eight children (55 boys, 33 girls) had one session of BoNT-A application, 26 (9 boys, 17 girls) had two, three boys had three and one girl had four. Eighteen children were "hemiplegic" and 100 were "diplegic". The study protocol was approved by the institutional board of review. A written informed consent was obtained from each patient and/or their families. The study was conducted in accordance with the principles of the Declaration of Helsinki.

Functional levels of the patients were determined using the gross motor function classification system (GMFCS). ${ }^{[7]}$ According to the GMFCS, 57 children were at levels I-II and 61 were at levels III-IV. Among 57 children with GMFCS levels of I-II, $50(88 \%)$ had one session of BoNT-A application, six had two and one had four. Of 61 children with GMFCS levels of III-IV, 38 (62\%) had one session of BoNT-A application, 20 had two and three had three.

Thomas test, Holt test (popliteal angle) and prone Ely test were used for the assessment of hip flexion (iliopsoas muscle) contracture, knee flexion (hamstring muscle group) contracture and knee extension (rectus femoris muscle) contracture, respectively. ${ }^{[8]}$ Hip adduction (hip adductor muscle group) contracture was assessed by measuring the amount of maximum hip abduction while the knees were fully extended. Ankle flexion contracture (gastrosoleus muscle) was evaluated by measuring the amount of maximum ankle dorsiflexion while the knees were fully extended. Negative values were defined as "equinus" and positive values as "dorsal flexion". Silverskiöld test was performed to understand whether the contracture was due to gastrocnemius muscle spasticity or due to gastrosoleus muscle spasticity. Gross motor function classification system levels and contracture examinations at pre-BoNT-A and post-BoNT-A applications were recorded. A three-month follow-up was considered sufficient to assess the maximum correction of the contracture, and the maximum obtained corrections within the first three months of BoNT-A application were recorded as post-BoNT-A values. All clinical examinations were performed by the same surgeon (senior author).

A previously defined $\mathrm{CP}$ management guide was followed in each case. ${ }^{[9]}$ BOTOX ${ }^{\circledR}$ (Allergan Inc., Irvine, California, USA) preparation of BoNT-A was used in this study. Every $100 \mathrm{u}$ was diluted with $4 \mathrm{~mL}$ of $0.9 \%$ sodium chloride. Targeted muscles according to careful initial planning were injected by the palpation technique. At least two injections, 
4-5 cm apart from each other, per muscle were performed under general mask anesthesia. An anatomical guideline was used for determining the most proper BoNT-A injection sites in the skeletal muscles of the lower limb. ${ }^{[10]}$ Supplemental casting in maximum corrected position was applied following the BoNT-A applications while the children were still under general mask anesthesia. All BoNT-A applications were performed by the same surgeon (senior author). BoNT-A was injected in the iliopsoas muscle in cases of hip flexion contracture, in the adductor longus muscle in cases of hip adduction contracture, in the rectus femoris muscle in cases of knee extension contracture and in the medial hamstring group muscles (gracilis, semitendinosus, semimembranosus) in cases of knee flexion contracture. Silverskiöld test was positive in all cases having an ankle flexion contracture, so BoNT-A was injected only in the gastrocnemius muscle in all these cases. The dose interval was commonly $1-2 \mu / \mathrm{kg}$ for the iliopsoas muscle, $1-2 \mu / \mathrm{kg}$ for the adductor longus muscle, $1-2 \mu / \mathrm{kg}$ for the rectus femoris muscle, 3-4 $\mu / \mathrm{kg}$ for the medial hamstring muscles and $4-5 \mu / \mathrm{kg}$ for the gastrocnemius muscle. There were 20 iliopsoas BoNT-A applications [mean dose: $1.3 \pm 0.5 \mu / \mathrm{kg}$, range: $0.5-2.2,95 \%$ confidence interval (CI): 1.0-1.5], 55 adductor longus (mean dose: $1.3 \pm 0.6 \mu / \mathrm{kg}$, range: $0.7-2.7,95 \%$ CI: $1.1-1.4)$, 15 rectus femoris (mean dose: $1.3 \pm 0.4 \mu / \mathrm{kg}$, range: 0.9-2.0, 95\% CI: 1.1-1.6), 152 medial hamstring (mean dose: $3.1 \pm 0.8 \mu / \mathrm{kg}$, range: $1.4-6.7,95 \%$ CI: $3.0-3.3$ ) and 219 gastrocnemius (mean dose: $4.4 \pm 0.8 \mu / \mathrm{kg}$, range: $2.4-7.7,95 \%$ CI: 4.3-4.5). Mean total dose was $10.2 \pm 4.1 \mu / \mathrm{kg}$ (range: $3.5-20,95 \%$ CI: 9.6-10.9) in 153 sessions. The duration of casting was 10 days and this was immediately followed by orthosis use and a physiotherapy period.

Obtaining less than $20^{\circ}$ of hip flexion contracture, more than $30^{\circ}$ of hip abduction, a negative prone Ely test, less than $50^{\circ}$ of popliteal angle and at least $5^{\circ}$ of ankle dorsiflexion at post-BoNT-A application were the initial aims. Post-BoNT-A quantitative data that complied with the above given ranges were considered sufficient improvement in the contracture and those that did not comply were considered as insufficient improvement.

\section{Statistical analysis}

Chi-square test was used to compare the frequencies of two groups and t-test for paired samples and Mann-Whitney $U$ test were used to compare the means of two groups. A $p$ value less than 0.05 was considered significant.

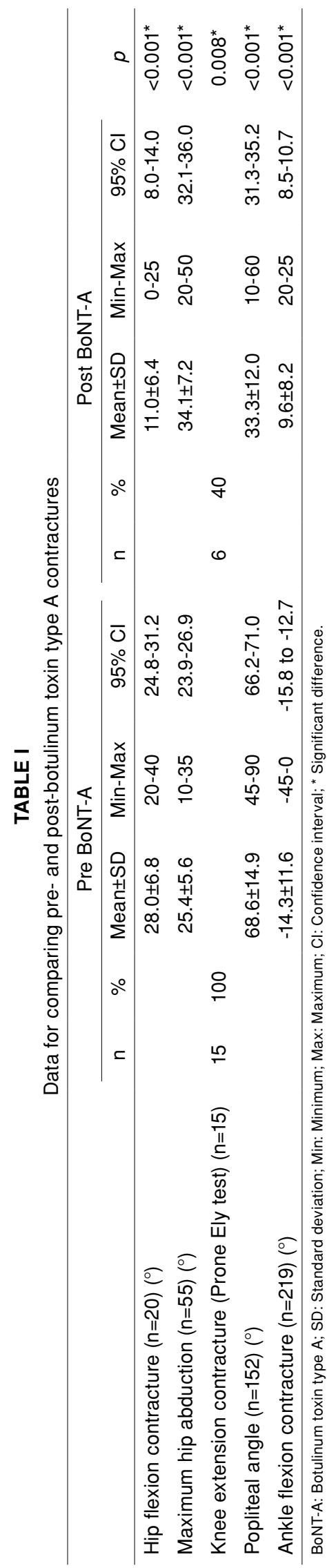


TABLE II

Correlation between improvement in lower limb contractures and several factors including age, gender

\begin{tabular}{|c|c|c|c|c|c|c|c|c|c|}
\hline & \multicolumn{4}{|c|}{ Sufficient improvement } & \multicolumn{4}{|c|}{ Insufficient improvement } & \multirow[b]{2}{*}{$p$} \\
\hline & $\mathrm{n}$ & Mean \pm SD & Min-Max & $95 \% \mathrm{Cl}$ & $\mathrm{n}$ & Mean $\pm S D$ & Min-Max & $95 \% \mathrm{Cl}$ & \\
\hline Hip flexion & & $7.2 \pm 2.4$ & $4-12$ & $5.9-8.5$ & & $7.3 \pm 2.1$ & $5-10$ & & \\
\hline Age (year) & & & & & & & & & 0.892 \\
\hline $\begin{array}{c}\text { Gender } \\
\text { Girl } \\
\text { Boy }\end{array}$ & $\begin{array}{c}6 \\
10\end{array}$ & & & & $\begin{array}{l}1 \\
3\end{array}$ & & & & 1.0 \\
\hline $\begin{array}{l}\text { GMFCS level } \\
\text { I-II } \\
\text { III-IV }\end{array}$ & $\begin{array}{c}2 \\
14\end{array}$ & & & & $\begin{array}{l}0 \\
4\end{array}$ & & & & 1.0 \\
\hline Initial hip flexion contracture $\left(^{\circ}\right)$ & & $25.3 \pm 4.3$ & $20-30$ & $23.0-27.6$ & & $38.8 \pm 2.5$ & $35-40$ & $34.8-42.7$ & $<0.001^{*}$ \\
\hline BoNT-A dose $(\mu / \mathrm{kg})$ & & $1.2 \pm 0.5$ & $0.5-2.2$ & $0.9-1.5$ & & $1.7 \pm 0.4$ & $1.3-2.0$ & $1.1-2.3$ & 0.099 \\
\hline \multicolumn{10}{|l|}{ Hip adduction } \\
\hline Age (year) & & $6.4 \pm 1.6$ & $4-10$ & $5.7-7.1$ & & $5.4 \pm 1.5$ & $3-8$ & $4.9-6.0$ & $0.023^{*}$ \\
\hline $\begin{array}{c}\text { Gender } \\
\text { Girl } \\
\text { Boy }\end{array}$ & $\begin{array}{c}16 \\
9\end{array}$ & & & & $\begin{array}{l}10 \\
20\end{array}$ & & & & $0.023^{*}$ \\
\hline $\begin{array}{l}\text { GMFCS level } \\
\text { I-II } \\
\text { III-IV }\end{array}$ & $\begin{array}{c}3 \\
22\end{array}$ & & & & $\begin{array}{c}2 \\
28\end{array}$ & & & & 0.650 \\
\hline Initial maximum hip abduction $\left({ }^{\circ}\right)$ & & $28.8 \pm 3.9$ & $20-35$ & $27.2-30.4$ & & $22.5 \pm 5.2$ & $10-30$ & $20.6-24.4$ & $<0.001^{*}$ \\
\hline BoNT-A dose $(\mu / \mathrm{kg})$ & & $1.3 \pm 0.5$ & $0.7-2.3$ & $1.1-1.5$ & & $1.3 \pm 0.5$ & $0.8-2.7$ & $1.1-1.5$ & 0.988 \\
\hline \multicolumn{10}{|l|}{ Knee extension } \\
\hline Age (year) & & $6.3 \pm 1.6$ & $5-9$ & $5.1-7.5$ & & $8.3 \pm 1.4$ & $7-10$ & $6.9-9.8$ & $0.026^{*}$ \\
\hline $\begin{array}{c}\text { Gender } \\
\text { Girl } \\
\text { Boy }\end{array}$ & $\begin{array}{l}4 \\
5\end{array}$ & & & & $\begin{array}{l}4 \\
2\end{array}$ & & & & 0.608 \\
\hline $\begin{array}{l}\text { GMFCS level } \\
\text { I-II } \\
\text { III-IV }\end{array}$ & $\begin{array}{l}5 \\
4\end{array}$ & & & & $\begin{array}{l}4 \\
2\end{array}$ & & & & 1.0 \\
\hline BoNT-A dose $(\mu / \mathrm{kg})$ & & $1.3 \pm 0.4$ & $1.0-2.0$ & $1.0-1.7$ & & $1.3 \pm 0.5$ & $0.9-2.0$ & $0.7-1.9$ & 0.456 \\
\hline \multicolumn{10}{|l|}{ Knee flexion } \\
\hline Age (year) & & $6.6 \pm 3.1$ & $3-16$ & $6.0-7.1$ & & $6.0 \pm 2.4$ & $4-13$ & $5.0-7.0$ & 0.381 \\
\hline $\begin{array}{c}\text { Gender } \\
\text { Girl } \\
\text { Boy }\end{array}$ & $\begin{array}{l}62 \\
66\end{array}$ & & & & $\begin{array}{c}7 \\
17\end{array}$ & & & & 0.082 \\
\hline $\begin{array}{l}\text { GMFCS level } \\
\text { I-II } \\
\text { III-IV }\end{array}$ & $\begin{array}{c}23 \\
105\end{array}$ & & & & $\begin{array}{c}0 \\
24\end{array}$ & & & & $0.026^{*}$ \\
\hline Initial popliteal angle $\left(^{\circ}\right)$ & & $65.0 \pm 13.2$ & $45-90$ & $62.7-65.3$ & & $87.9 \pm 5.9$ & $70-90$ & $85.4-90.4$ & $<0.001^{*}$ \\
\hline BoNT-A dose $(\mu / \mathrm{kg})$ & & $3.2 \pm 0.8$ & $1.4-6.7$ & $3.0-3.3$ & & $3.0 \pm 0.5$ & $1.5-3.6$ & $2.8-3.3$ & 0.387 \\
\hline Ankle flexion & & & & & & & & & 0.444 \\
\hline Age (year) & & $5.5 \pm 1.9$ & $2.5-11$ & $5.2-5.8$ & & $5.7 \pm 1.8$ & $4-13$ & $5.2-6.2$ & $0.007^{*}$ \\
\hline $\begin{array}{c}\text { Gender } \\
\text { Girl } \\
\text { Boy }\end{array}$ & $\begin{array}{c}65 \\
104\end{array}$ & & & & $\begin{array}{l}30 \\
20\end{array}$ & & & & $0.001^{*}$ \\
\hline $\begin{array}{l}\text { GMFCS level } \\
\text { I-II } \\
\text { III-IV }\end{array}$ & $\begin{array}{l}72 \\
97\end{array}$ & & & & $\begin{array}{c}8 \\
42\end{array}$ & & & & $<0.001^{*}$ \\
\hline Initial ankle flexion contracture $\left(^{\circ}\right)$ & & $-10.9 \pm 9.8$ & $-40-0$ & $-12.3-9.4$ & & $-25.8 \pm 9.5$ & $-45--10$ & $28.5-23.1$ & 0.031 \\
\hline BoNT-A dose $(\mu / \mathrm{kg})$ & & $4.4 \pm 0.7$ & $2.6-6.0$ & $4.2-4.5$ & & $4.7 \pm 1.0$ & $2.4-7.7$ & $4.4-5.0$ & \\
\hline
\end{tabular}




\section{RESULTS}

A significant decrease from $28^{\circ}$ to $11^{\circ}$ in mean hip flexion contracture of 20 cases at post-BoNT-A application was recorded $(\mathrm{p}<0.001)$ (Table I). A sufficient improvement was observed in 16 cases $(80 \%)$ (Table II). A sufficient improvement could not be achieved for hips in which the initial flexion contracture was higher (Table II). Age, gender, GMFCS level and BoNT-A dose did not affect the outcome in these cases (Table II).

Although mean maximum hip abduction increased considerably at post-BoNT-A application (from $25.4^{\circ}$ to $34.1^{\circ}$ ), a sufficient improvement could be observed in 25 of 55 cases (45\%) (Tables I and II). The risk of obtaining insufficient improvement was higher in younger children, in boys and in hips in which the initial maximum hip abduction was smaller (Table II). Gross motor function classification system level and BoNT-A dose did not affect the outcome (Table II).

Positive prone Ely test disappeared in nine of 15 cases $(60 \%)$ at post-BoNT-A application in the rectus femoris muscle (Table I). Mean age of the patients with sufficient improvement was younger than those with insufficient improvement (Table II). Gender, GMFCS level and BoNT-A dose did not affect the outcome in such cases (Table II).

Mean popliteal angle of the cases was significantly lower at post-BoNT-A application compared to pre-BoNT-A (Table I). A sufficient improvement was seen in 128 of 152 cases (84\%) with an initial knee flexion contracture (Table II). Insufficient improvement was higher in cases with higher GMFCS levels and with higher initial popliteal angles (Table II). Age, gender and BoNT-A dose did not affect the outcome in such cases (Table II).

There was a significant difference between pre-BoNT-A and post-BoNT-A mean ankle flexion contracture values (Table I). A sufficient improvement in the ankle equinus contracture was observed in 169 of $219(77 \%)$ cases in which BoNT-A application was performed in the gastrocnemius muscle (Table II). The risk of obtaining insufficient improvement was two times higher in girls than in boys, three times higher in cases with GMFCS levels III-IV than in cases with GMFCS levels I-II and significantly higher in cases with a higher initial ankle flexion contracture (Table II).

Mild to moderate pain was seen for a period of a maximum of 72 hours in the affected muscles due to stretching following casting in almost all patients.
A short-term fever of more than $38.3^{\circ} \mathrm{C}$ within the first 48 hours at post-injection was seen in two patients.

\section{DISCUSSION}

Since the introduction of BoNT-A injection in the treatment of spastic type $\mathrm{CP}$, several studies have reported favorable results in the treatment of both upper and lower extremity contractures. A significant improvement was reported in joint mobility and reduction of spasticity compared to pretreatment values and a significant improvement was also seen in gross motor function after 12 months of BoNT-A treatment. ${ }^{[11-13]}$ In a double blind randomized trial, use of BoNT-A adjunct to physical and occupational therapy was found to improve care and comfort goals in non-ambulatory $\mathrm{CP}$ children and to increase the satisfaction of parents of such children. ${ }^{[2]}$ In a randomized comparative study conducted in ambulatory children with $\mathrm{CP}$ spastic diplegia, BoNT-A injections revealed superior effects in terms of reduction in spasticity and improvement in range of motion (ROM) and functional outcome measures than phenol blocks. ${ }^{[14]}$ In a retrospective study reviewing the results of 424 children with $\mathrm{CP}$, it was found that BoNT-A delayed and reduced the frequency of surgical procedures. ${ }^{[15]}$

Proper muscle selection, an appropriate dosage and accurate injection technique are the key points for obtaining better functional outcomes following BoNT-A injections. ${ }^{[16]}$ In addition, aftercare issues such as casting, physical therapy and orthotic management also significantly influence the clinical outcomes. An extended clinical examination followed by gait analysis or video evaluation is recommended to select the right muscles. Although there is still debate among physicians, computerized gait analysis can offer a more accurate and objective assessment of gait in the treatment planning of $\mathrm{CP}$ patients. Gait analysis was considered useful in confirming clinical indications for surgery, in defining indications for surgery that had not been clinically proposed and postponing or delaying surgery that had been clinically proposed. BoNT-A injections of the lower limbs under the guidance of gait analysis revealed favorable results in children with $\mathrm{CP} \cdot{ }^{[15,17]}$

The results of the present study revealed significant improvement in ROM of the hip, knee and ankle joints following BoNT-A injections. The most prominent improvement was seen in hip, knee and ankle flexion $\mathrm{ROM}^{[18]}$ while in about half of the cases with hip adduction contracture, a sufficient improvement could not be obtained. After analyzing 
our entire clinical and radiographic data of the $\mathrm{CP}$ patients, we decided to be more aggressive when treating hip instability and changed our regime concerning the treatment of hip adduction contracture in $\mathrm{CP}$ patients and have been performing open adductor tenotomy, not adductor BoNT-A injection, since then. When performing adductor tenotomy, we have been performing iliopsoas tenotomy at the lesser trochanter through the same incision if needed in order to treat hip instability, so the number of iliopsoas BoNT-A injections has significantly decreased in our hands. We currently believe that the most favorable effects of BoNT-A can be seen in treating knee and ankle flexion contractures and this has been supported by our findings. Our findings are in parallel with the findings of Koman et al., ${ }^{[19]}$ where they have treated equinus deformity of the ankle with BoNT-A and reported that the BoNT-A group demonstrated increased ankle ROM and improved gait function.

To date, various studies ${ }^{[1,2,9]}$ have investigated BoNT-A injections in terms of single versus multiple injections in a single session, use of concomitant orthosis, casting, timing of injections, ideal dose for different muscle groups, age and body mass index of children. The current study evaluated the influence of age, gender, functional level of the patient, severity of initial contracture and BoNT-A dose on outcomes of BoNT-A treatment in children with spastic type $\mathrm{CP}$ with contractures of the lower limb. The results of the present study revealed that the severity of initial contracture could be the most important determinant of the clinical outcome in the lower limbs. Based on the assessment of $95 \%$ CI of the mean values, an initial hip flexion contracture of more than $30^{\circ}-35^{\circ}$, an initial maximum hip abduction of less than $20^{\circ}-25^{\circ}$, an initial popliteal angle more than $70^{\circ}$ and an initial ankle flexion contracture exceeding $15^{\circ}-20^{\circ}$ can be considered as the cut-off values correlated with an increased risk of insufficient improvement at post-BoNT-A injection. Based on the results of the present study, we may say that age of the patient influences the clinical outcome in hip adductor and rectus femoris injections, and gender in hip adductor and gastrocnemius injections. Better ROM can be obtained in knee and ankle joints if the patients have GMFCS I and II levels initially. In addition, patients with GMFCS I and II levels have about a three times lower rate of repeated BoNT-A injections than patients with GMFCS III and IV levels.

Injection of BoNT-A should be performed into the motor end plate zones of the affected muscles. We have been using the palpation technique by following the anatomical guidelines describing the localization of the motor end plate zones of the frequently injected muscles, ${ }^{[10]}$ and our data support the use of this technique in improving the clinical outcome of the patients.

In most of the children with multilevel involvement, multilevel BoNT-A injections are needed, so higher total dosages are injected to gain optimal treatment outcomes. ${ }^{[1]}$ We observed that BoNT-A doses of sufficient and insufficient improvement groups were similar for all sites. Thus although an insufficient clinical improvement seems to be mainly dependent on the initial severity of contracture, a better improvement could have been attained by increasing the dose, particularly in cases exceeding the previously mentioned ROM cut-off values. However, while increasing the dose for certain sites, it is mandatory to follow the maximum total dose recommendations. ${ }^{[16]}$ In the present study, the maximum total dose was $20 \mu / \mathrm{kg}$. It was reported that there was no evidence of a cumulative effect on adverse effects of repeated BoNT-A treatment in pediatric patients with $\mathrm{CP} \cdot{ }^{[20,21]}$ The most frequent treatment-related adverse event was injection site pain. In the current study, mild to moderate pain in the affected muscles due to stretching following casting was the most commonly seen complication. We did not come across any significant systemic side effects during the therapy, even in patients having repeated injections.

The authors' post-BoNT-A application protocol is: immediate casting for 10 days, followed by orthosis and a physical therapy program. Post-BoNT-A cast application was reported to have beneficial effects for obtaining better improvement in the gait. ${ }^{[22]}$ We do not have scientific comparative data exactly proving the need for short-term cast application after BoNT-A injection; however, the results obtained from this study seem to support the benefits of this regime.

This study evaluated the clinical outcomes of children who were treated by BoNT-A injections in the muscles of the lower limbs due to spastic type CP. However, the limitations of the current study should be noted. The study did not contain any control group and the change in functional levels in children could not be evaluated due to incomplete post-injection GMFCS level records. The results are based on measurements obtained from clinical examinations only, and there was no data comparing BoNT-A with other treatment modalities. In addition, there was no detailed data concerning the rate of further 
surgical procedures for all patients in the present study. Moreover, although a meticulous clinical examination followed by careful muscle selection and dose planning was performed by the same experienced surgeon in the treatment of $\mathrm{CP}$ patients, the absence of computerized or video gait analysis of all patients at pre- and post-BoNT-A injection was the main shortcoming of the present study. This was due to a lack of a gait analysis laboratory at the institution where the study was conducted. A limited number of patients had computerized gait analysis results from other centers or objective gait scores by visual gait analysis but this limited data were not taken into consideration. Nevertheless, the data obtained from a considerable number of patients by meticulous clinical examination of an experienced surgeon can be considered valuable.

In conclusion, BoNT-A injection followed by shortterm casting and effective physical therapy in the treatment of lower limb contractures in spastic type $\mathrm{CP}$ in children significantly improves the ROM in hip, knee and ankle joints. With the figures available from the present study, initial level of contracture seems to be the main determinant of improvement in the ROM of the lower limbs at post-BoNT-A injection. Age, gender and GMFCS level are the other factors that may influence the clinical outcome for certain sites. It may be better to increase the BoNT-A dose in cases having ROM values exceeding cut-off values in certain lower limb joints, as defined in the present study, in order to obtain better clinical results.

\section{Declaration of conflicting interests}

The authors declared no conflicts of interest with respect to the authorship and/or publication of this article.

\section{Funding}

The authors received no financial support for the research and/or authorship of this article.

\section{REFERENCES}

1. Molenaers G, Fagard K, Van Campenhout A, Desloovere $\mathrm{K}$. Botulinum toxin A treatment of the lower extremities in children with cerebral palsy. J Child Orthop 2013;7:383-7.

2. Copeland L, Edwards P, Thorley M, Donaghey S, Gascoigne-Pees L, Kentish M, et al. Botulinum toxin A for nonambulatory children with cerebral palsy: a double blind randomized controlled trial. J Pediatr 2014;165:140-6.

3. Ferrari A, Maoret AR, Muzzini S, Alboresi S, Lombardi F, Sgandurra G, et al. A randomized trial of upper limb botulimun toxin versus placebo injection, combined with physiotherapy, in children with hemiplegia. Res Dev Disabil 2014;35:2505-13.

4. Ade-Hall RA, Moore AP. Botulinum toxin type A in the treatment of lower limb spasticity in cerebral palsy. Cochrane Database Syst Rev 2000;2:CD001408.
5. Oto M, Sarıkaya İA, Erdal OA, Şeker A. Surgical reconstruction of hip subluxation and dislocation in children with cerebral palsy. Eklem Hastalik Cerrahisi 2018;29:8-12.

6. Reddihough DS, King JA, Coleman GJ, Fosang A, McCoy AT, Thomason $P$, et al. Functional outcome of botulinum toxin A injections to the lower limbs in cerebral palsy. Dev Med Child Neurol 2002;44:820-7.

7. Palisano R, Rosenbaum P, Walter S, Russell D, Wood E, Galuppi B. Development and reliability of a system to classify gross motor function in children with cerebral palsy. Dev Med Child Neurol 1997;39:214-23.

8. Trost J. Physical assessment and observational gait analysis. In: Gage. JR, editor. The treatment of gait problems in cerebral palsy. London: Mac Keith Press; 2004. p. 71-89.

9. Heinen F, Molenaers G, Fairhurst C, Carr LJ, Desloovere K, Chaleat Valayer E, et al. European consensus table 2006 on botulinum toxin for children with cerebral palsy. Eur J Paediatr Neurol 2006;10:215-25.

10. Van Campenhout A, Molenaers G. Localization of the motor endplate zone in human skeletal muscles of the lower limb: anatomical guidelines for injection with botulinum toxin. Dev Med Child Neurol 2011;53:108-19.

11. Delgado MR. The use of botulinum toxin type A in children with cerebral palsy: A retrospective study. Eur J Neurol 1999;6:11-8.

12. Gormley ME, Gaebler-Spira D, Delgado MR. Use of botulinum toxin type $\mathrm{A}$ in pediatric patients with cerebral palsy: a three-center retrospective chart review. J Child Neurol 2001;16:113-8.

13. Linder M, Schindler G, Michaelis U, Stein S, Kirschner J, Mall V, et al. Medium-term functional benefits in children with cerebral palsy treated with botulinum toxin type A: 1-year follow-up using gross motor function measure. Eur J Neurol 2001;8:120-6.

14. Gonnade N, Lokhande V, Ajij M, Gaur A, Shukla K. Phenol versus botulinum toxin a injection in ambulatory cerebral palsy spastic diplegia: A comparative study. J Pediatr Neurosci 2017;12:338-43.

15. Molenaers G, Desloovere K, Fabry G, De Cock P. The effects of quantitative gait assessment and botulinum toxin a on musculoskeletal surgery in children with cerebral palsy. J Bone Joint Surg [Am] 2006;88:161-70.

16. Molenaers G, Van Campenhout A, Fagard K, De Cat J, Desloovere $\mathrm{K}$. The use of botulinum toxin $\mathrm{A}$ in children with cerebral palsy, with a focus on the lower limb. J Child Orthop 2010;4:183-95.

17. Lofterød B, Terjesen T. Results of treatment when orthopaedic surgeons follow gait-analysis recommendations in children with CP. Dev Med Child Neurol 2008;50:503-9.

18. Atik OŞ. Which articles do we prefer to publish? Eklem Hastalik Cerrahisi 2018;29:1.

19. Koman LA, Brashear A, Rosenfeld S, Chambers H, Russman $\mathrm{B}$, Rang $\mathrm{M}$, et al. Botulinum toxin type a neuromuscular blockade in the treatment of equinus foot deformity in cerebral palsy: a multicenter, open-label clinical trial. Pediatrics 2001;108:1062-71.

20. Albavera-Hernández C, Rodríguez JM, Idrovo AJ. Safety of botulinum toxin type A among children with spasticity secondary to cerebral palsy: a systematic review of randomized clinical trials. Clin Rehabil 2009;23:394-407. 
21. Delgado MR, Bonikowski M, Carranza J, Dabrowski E, Matthews D, Russman B, et al. Safety and efficacy of repeat open-label abobotulinumtoxina treatment in pediatric cerebral palsy. J Child Neurol 2017;32:1058-64.
22. Desloovere K, Molenaers G, Jonkers I, De Cat J, De Borre L, Nijs J, et al. A randomized study of combined botulinum toxin type A and casting in the ambulant child with cerebral palsy using objective outcome measures. Eur J Neurol 2001;8:75-87. 